\title{
Students' Participation in Accreditation: The Experience of the Republic of Kazakhstan
}

\author{
Aliya Assylbekova $^{1} \&$ Sholpan Kalanova ${ }^{2}$ \\ ${ }^{1}$ L. N. Gumilyov Eurasian National University, Kazakhstan \\ ${ }^{2}$ Independent Kazakhstan Quality Assurance Agency for education, Astana, Republic of Kazakhstan \\ Correspondence: Aliya Assylbekova, Mirzoyan st., 2, Astana, 010008, Kazakhstan. E-mail: ali209@yandex.ru
}

$\begin{array}{lc}\text { Received: November 17, } 2014 \quad \text { Accepted: December 20, } 2014 \quad \text { Online Published: February } 25,2015 \\ \text { doi:10.5539/ass.v11n6p294 } & \text { URL: http://dx.doi.org/10.5539/ass.v11n6p294 }\end{array}$

\begin{abstract}
Globalization requires appropriate level of quality in higher education, which could be reached by accreditation of higher education institutions and programs. This procedure includes involvement of the students. During a decade a big deal of progress was taken place. However, this area is less studied, especially on Kazakhstani context. Thus, the purpose of the paper is to reveal the role of students involved in accreditation by one of Kazakhstani accreditation agencies. Even though, the accreditation was launched in 2001, the actual its implementation started only few years ago, which is followed by series of reforms in this area. One of the main aspects was the engagement of students, which was not considered widely. Thus, the results of this study are unique in some extent. Current research is based on empirical research of 2013, conducted in 1 out of 2 national accreditation agencies of Kazakhstan. The results of the study show that students, involved in accreditation, experience difficulties with lack of guidance, provided by agency, appropriate knowledge and skills of the students. Nevertheless, students are perceived as full partners during the accreditation process. Moreover, they consider the practice of student-experts as a useful life and professional experience.
\end{abstract}

Keywords: higher education, quality assurance, accreditation, students

\section{Introduction}

Currently one of the key factors in assuring the quality of higher education is accreditation (Hernes et al., 2008). Republic of Kazakhstan (RK) defines education and ensuring its quality among the leading strategic objectives, since accreditation is the key to integration into the European Higher Education Area and the mutual recognition of documents on education with the countries - members of the Eurasian Economic Community (EurAsEC) and the Commonwealth of Independent States(CIS) (European Commision,1999; Decree of the President of the Republic of Kazakhstan, 2004; Agreement between the Government of the Republic of Belarus, the Republic of Kazakhstan, the Kyrgyz Republic, the Russian Federation and the Government of the Republic of Tajikistan, 1998). Moreover, by 2020, 65\% of universities in Kazakhstan will be an independent national accreditation of universities and 30\% will be independent institutional accreditation by international standards (Decree of the President of the Republic of Kazakhstan, 2004).

According to international requirements accreditation needs students` involvement. During a decade a big deal of progress was taken place in Kazakhstani quality assurance. However, this area is still less examined in Kazakhstan. Thus, the purpose of the article is to reveal the role of students ' participation in accreditation, conducted by one of Kazakhstani agencies. Although, the accreditation was established in 2001, the factual its implementation began few years ago. One of the main aspects was students' involvement. Therefore, the findings of this study are unique in some extent.

The study is based on empirical research of 2013, conducted in 1 out of 2 national accreditation agencies of Kazakhstan. The results of the study show that students, involved in accreditation, experience difficulties with lack of guidance, provided by agency, appropriate knowledge and skills of the students. Nevertheless, students are perceived as full partners during the accreditation process. Moreover, they consider the practice of student-experts as a useful life and professional experience. 


\section{Accreditation in Kazakhstan}

\subsection{Background}

During the years of independence, Kazakhstan has established the National System of Education Quality Assessment, which consists of the elements of an independent external evaluation (licensing, certification, accreditation, rating, the unified national testing, the intermediate state control, comprehensive testing of applicants and others) (Decree of the President of the Republic of Kazakhstan, 2004).

First basic provisions on the accreditation of universities of Kazakhstan had been prescribed in the Law "On Education" in 1999, according to which the state accreditation was a mandatory procedure (The Law On Education, 1999). However, the actual accreditation of universities was introduced only in 2001. Initially, the state accreditation and certification were carried out simultaneously by the Ministry of Education and Science of RK. The decision on accredit of universities was mainly made on the basis of state certification results by Accreditation Council. The Accreditation Council included representatives of public authorities and education institutions and Parliament deputies (The resolution of the Government of the Republic of Kazakhstan "On approval of the state accreditation of educational organizations, 2001).

Register of accredited universities, the position of the Accreditation Board and the model provisions (instructions, regulations) were developed and approved by the Ministry of Education and Science of the RK (The Law On Education, 1999).

As a result, in 2001, 59 (47 public and 12 private) out of 182 universities were accredited. However, the methodology of state accreditation of universities was based on the collection and analysis of quantitative indicators only. This drew sharp criticism from the private universities. In this regard, accreditation was postponed for a few years (Kalanova, 2012; Kalanova et al., 2009).

In 2007, according to the new provisions of the Education Act, accreditation has been undertaken on a voluntary basis and received the status of a national procedure. However, these measures did not adequately stimulate universities to undergo accreditation. For example, in 2009, 9 out of 148 universities and in 201024 of 149 accredited universities (National Center for Education Quality Assessment, 2011).Thus, the following reforms have been undertaken in the area of quality assurance and education in general.

In December, 2010, the State Program of Education Development for 2011-2020 was signed a presidential decree and adopted. It stipulates that from 2012 accreditation will be conducted by non-profit non-governmental organizations (Decree of the President of the Republic of Kazakhstan On Approval of the State Program of Education Development of the Republic of Kazakhstan for 2011-2020, 2010).

In October 24, 2011, the Parliament had made amendments to the existing Law "On Education", whereby the role of accreditation was significantly strengthened. The amendments to the Act enshrined the presence of a transition period until 2014-2015. During this period accreditation and state certification will be carried out simultaneously. State certification will be undertaken only in the non-accredited universities and non-accredited educational programs. Then in late 2011, the Minister of Education and Science of the RK signed the Order on the procedure and the requirements for maintaining a national registry of accreditation bodies.

\subsection{Current Accreditation State in Kazakhstan}

In line with the Law "On Education" the task of universities accreditation was transferred from governmental to non-governmental sector. However, the state will regulate the accreditation of suppliers by their recognition procedures and inclusion in the National Register of accredited bodies (Law on Education, 1999). It was issued in May, 2012, by the Republican Accreditation Board. The following 6 accrediting agencies entered in the list of this Register:

1) Independent Kazakhstan Quality Assurance Agency for Education (Kazakhstan)

2) An independent agency of accreditation and rating (Kazakhstan)

3) The accreditation agency program engineering, computer science, natural sciences and mathematics (Germany)

4) Institute for Accreditation, Certification and Quality (Germany)

5) Austrian Agency for Quality Assurance (Austria)

6) The Accreditation Council for Engineering and Technology (USA).

To motivate HEIs to gain accreditation, all HEIs, accredited by 2014-2015 will be disburdened from attestation and they will be eligible to apply for state funding for undergraduate and postgraduate (taught) courses. From 
2015 the state attestation is planned to be completely replaced by a national institutional and specialized (program) accreditation of HEIs and colleges. In addition, the accredited institutions with accredited educational programs will have the right to issue diplomas, which will be recognized by the State (Decree of the President of the Republic of Kazakhstan On Approval of the State Program of Education Development of the Republic of Kazakhstan for 2011-2020, 2010).

\section{Literature review}

\subsection{International Experience}

Engaging students in quality assurance is one of the $\mathrm{c}$ issues and the basic principles of a culture of quality in the global educational environment (European University Association EUA, 2010, NAAC, 2007). Since 2001, as part of the Bologna process, students are treated as partners to ensure the quality of higher education. For example, according to the Prague Communique students were recognized as full members of the higher education system. Moreover, their participation was a prerequisite of quality assurance (Bologna process, 2001). However, in 2003 the majority of student organizations had only the right to vote in the quality assurance process ( 28 of 50) and accreditation ( 21 of 50), while only a small portion of their representatives received or planned to get a membership in the Accreditation Board. Moreover, in a number of European countries the system of quality assurance and accreditation had not yet been formed yet (The European Students' Union, 2003).

As a result of the Berlin communiqué of 2005 students became more involved in the evaluation process of educational programs. (Bologna process, 2003; ENQA, 2005). Student organizations were perceived as partners at the international, national and institutional levels (OECD, 2005; UNESCO, 2005). Another catalyst in this regard was the $\mathrm{E} 4$, the basic principle of which is the involvement of stakeholders in the process of ensuring the quality of higher education. Over the past 10 years substantial progress has been taken place in this field. Today a significant portion of the student organizations of the Bologna process (17 out of 37 in internal audit, 19 of 32 in the external audit, 16 of 28 in the accreditation process/audit, and 15 of 30 part of the accreditation council) believes that students are full partners in quality assurance and higher education in general (The European Students 'Union, 2012). Nevertheless, the results of studies of the European students' Union show that students are not sufficiently involved in the quality assurance process (European Student `s Union, 2013).

In the USA, the engagement of students in the Accreditation Council as a member of the public is of recommendatory nature (Council for Higher Education Accreditation, 1998). Students can be elected in the membership of the agencies' board as a public representative (Council for Higher Education Accreditation, 1998). In fact $1 / 7$ of the accreditation board is public representatives. But currently there are no students in the boards of regional accrediting associations and in the panel. Since the representatives of the teaching staff and the leaders of universities are appointed to this position (The New England Association of Schools and Colleges, 2013; North Central Association of Colleges and Schools, 2013; The Southern Association of Colleges and Schools Commission on Colleges, 2013 ; The Western Association of Schools and Colleges, 2013).

According to above stated, it can be concluded that in the countries of the Bologna process and in the United States, the participation of students in the process of quality assurance is more of a recommendation than obligatory. In first case it is expected to attract students to the external audit, while in the USA students are not involved in the external audit as teaching staff and leaders of universities are assigned for these positions. Moreover, in most of the regional accrediting agencies of the USA students are not actually included in the board.

\subsection{Involving Students in the Process of Accreditation of Higher Education Institutions}

As it was stated before the students ' participation in higher education accreditation is considered as one of the key agendas in the world. However it has not been studied widely in the literature. Most of the literature concern general issues of students' involvement in quality assurance process.

Analysis of international reports shows that the following levels of participation of students in quality assurance process: institutional, national and international (Education, Audiovisual and Culture Executive Agency, 2012) or internal, external and national (Palomares, 2012).

The role of students at internal or institutional level includes 1) the provision of information (through the answers to the questionnaires on a regular basis, participation in focus groups and etc.), 2) assisting in the preparation of reports on self-assessment as members of a self-assessment group (preparation of reports, commenting on reports and etc.), 3) membership in the board of the internal quality assurance of the university.

At the external level, students provide information as university students or serve in the role of experts for the external audit of the program or the university (Dearlove in Palomares, 2012, p. 365). For example, according to 
results of survey, conducted by European Association for Quality Assurance in Higher Education (ENQA) in a number of European countries, agencies involve students in the following processes of quality assurance:

1) the accreditation of experts (in the role of leaders and members of the group);

2) external auditors (Dearlove, 2006).

At the national level, students are involved directly in the work of quality assurance agencies: 1) participate in the planning process of accreditation procedures, and 2) are presented as a member of the advisory or administrative authority.

The roles of students, involved in external quality assurance of higher education, are:

1) learners, the only group of people who are capable of perceiving the circumstances from students point of view;

2) experienced spokespersons of student community;

3) investors of time and funds in higher education, stakeholders (Brenders et al. in Elassy, 2013, p. 166);

4) full members of boards (Wiberg, 2006).

In external quality assurance process the students- experts are selected by means of arranged competition among students and student representatives or/and on the basis of student representatives' recommendation. The responsibilities of students, in some cases could be either similar or different from other experts` competences depending on considered country. They are assumed to

1) "be a current or recently graduated student of higher education institution" (Dearlove, 2006, p. 34);

2) be familiar with the subject to be reviewed (for instance, in program accreditation);

3) have a background in quality assurance and management/leadership issues in higher education institution;

4) have practice in school or university governance;

5) have critical thinking and communication skills;

6) be aware of higher education.

In addition, the provision of training before the accreditation is various from country to country. For instance, in most of 31 questionnaired agencies, members of European Association for Quality Assurance in Higher Education (ENQA), which are from 17 European countries, the trainings are not provided for students before the accreditation is proceed (Dearlove, 2006). However, there are arguments in the world on whether the students are appropriate experts candidates to be recruited in panel. Some resources doubt the involvement of students in quality assurance, since they do not have relevant background, knowledge, skills and flexibility in time comparing to professional experts. Furthermore, low level of motivation and legislation features could be one of the challenges in students` participation in accreditation (NUS in Elassy, 2013, p. 169).

\section{Methodology}

The purpose of the research was to identify the role of students in the process of accreditation of higher education institutions of Kazakhstan.

A case study, mixed method research approach, questionnaire and interviews methods were applied. A case study approach was applied to provide in depth study of student engagement practice of accreditation agency in Kazakhstan. Thus, mixed method approach was utilized. The questionnaire was used to collect data from respondents in the distance. Moreover, to ensure the availability and mobility of online survey questionnaire was used "Monkey survey". Interview was used to provide insight into the research aspect. The questions of the questionnaire and the interview were based on ENQA (2006) survey. Specifics and shortcomings of using questionnaire and interview instruments were taken into account during the study.

Current research is based on empirical research of 2013, conducted in 1 out of 2 national accreditation agencies of Kazakhstan. The sample included 1-3 years students of undergraduate and postgraduate courses of Kazakhstani universities. They were involved in the accreditation of Kazakhstani higher education institutions. The total number of respondents is 16 out of 16 students attracted by studied agency as experts and members of Board. In addition, the interview was conducted with the representative of the above stated accreditation agency.

Because of the ethical reasons detailed information on sample agency and respondents is not provided in the study.

The results of this study cannot be generalized to the entire system of higher education and accreditation in 
Kazakhstan. They are applicable to considered agency only.

\section{Results and Analysis}

\subsection{Results}

Analysis of the results of the field research shows that the sample agency's practice of student involvement in accreditation mostly corresponds to its international analogue. However, the implementation of this practice differs in some extent. This will be discussed further.

The agency involves students in different levels of quality assurance process (accreditation). They take part at internal level as students of reviewed university (providing information, preparation self-report) and at external level as student-experts of external audit and Board members (decision-making process) (Dearlove, 2006; Wiberg, 2006).

"The students are fully engaged in the process of accreditation, carried out by the agency, during interview as consumers, in institutional and program accreditation as experts and Board members".

Representative of the sample agency

It was revealed that students from the sample are mostly engaged as experts during external audit, especially in institutional accreditation. Simultaneously with the role of experts, some of the students are the members of the Board on institutional and program/specialized accreditation (Table 1).

Table 1. Types of students' involvement (out of 16 expert and Board member students)

\begin{tabular}{llll}
\hline & $\begin{array}{l}\text { Institutional accreditation of } \\
\text { higher education institutions }\end{array}$ & $\begin{array}{l}\text { Program/specialized accreditation } \\
\text { higher education institutions }\end{array}$ & Total \\
\hline $\begin{array}{l}\text { Expert in external } \\
\text { audit }\end{array}$ & $\mathbf{8 7 , 5 \%}$ & $\mathbf{1 2 , 5 \%}$ & 16 \\
$\begin{array}{l}\text { Member of } \quad 14 \\
\text { accreditation Board }\end{array}$ & $\mathbf{1 8 , 7 5 \%}$ & 2 & \\
\hline
\end{tabular}

In addition, main criteria for selection of student - experts and Board members in the considered Kazakhstani agency correlate with their foreign counterparts:

1) student status;

2) appropriate knowledge and experience in the field of higher education, quality assurance and volunteering;

3) high performance.

For instance, the vast majority of students have had expert experience in social activities (volunteering) in higher education $(54,55 \%)$.

According to answers of the representative of the agency and questionnaired students all involved students are instructed and get guidance before the start of accreditation process. However, this guidance is not delivered in full. To the question "Does the accreditation agency provide appropriate guidance for you before engaging in the accreditation process?" $81,82 \%$ of respondents said that the agency do not provide full guidance on accreditation procedures for involved students. This practice slightly does not coincide with international experience where in most cases, agencies conduct training sessions for students of experts to prepare them for accreditation.

Table 2. Main obstacles, faced by the student-experts and board members, attracted by sample agency

\begin{tabular}{ll}
\hline Main obstacles & $\%$ \\
\hline lack of information and instructions & $\mathbf{2 5 \%}$ \\
& 4 \\
lack of necessary knowledge and skills of the students to participate in accreditation & $37.5 \%$ \\
& 6 \\
\hline
\end{tabular}


Next, it was found out that main difficulties, faced by student-experts are:

1) lack of information and instructions- $25 \%$

2) lack of necessary knowledge and skills of the students to participate in accreditation-37,5\% (Table 2).

In this case respondents believe that the agency ought to identify goals and objectives (what part of the work they carry out) of the work. They conceive that special courses should be conducted for students, since they do not always have adequate professional experience and knowledge in quality assurance and higher education. Moreover, they noted the need of briefing and examples of report to be provided before accreditation.

"I need more clear guidance on purposes and objectives of the work I have to do. Then I feel lack of experience, thus, it would be extremely useful if I take part in training, briefing or course on my core duties during the audit. Finally, it would be helpful if I could have an example or guidance on preparing report of the external audit".

One of the student-experts

\subsection{Analysis}

Nevertheless, according to the majority $(54,55 \%)$ of respondents and the information, provided by the agency representative, the students opinion is taken into account in full during accreditation and the agency consider students as an equal partner. Moreover, a number of respondents believe that the participation of students in accreditation as experts and Board members is useful in enriching their life and professional experiences.

The study of the students' role in accreditation of the results of the field research shows that the agency's practice of student involvement in accreditation mostly coincides with international experience. However, the implementation of this practice differs in some extent. The students are conceived as equal partners in accreditation, but they are not provided with the adequate support.

As it was stated above the full implementation of accreditation has been taken place only for few years. Thus, during the analysis the effect of the short time frame and little experience of Kazakhstan in implementing accreditation, as well as little experience of the sample agency in involving students was taken into account.

Although, the research assisted to discover above stated issues, it has particular shortcomings. Little sample and consideration only one agency limits the generalizability of the research results. A larger sample and involvement of the second Kazakhstani accreditation agency would have reinforced a validity and reliability of the research as well as could have provided more comprehensive picture of the explored phenomenon.

The undertaken study was considered to be useful for focusing on the aspects of the student's role in accreditation, which used to be underestimated in Kazakhstani higher education and quality assurance. Due to a lack of prior research in this area in Kazakhstan context, the research built a foundation and suggested essential suggestions for further investigations in this area.

\section{Conclusion}

Emerging requirements for the quality of higher education put forward by international educational community require a new approach and appropriate measures. Today, more and more countries pay close attention to the quality of higher education and take concrete steps to promote accreditation and improvement of its appropriate mechanisms. As a result, one of the main consumers of higher education-students have been actively involved in the accreditation as a peer experts in the external audit and accreditation boards.

During the years of independence of Kazakhstan a number of reforms in this direction were taken place: regulatory and legal framework, standards and criteria for accreditation were developed, a national registry of accreditation bodies was created, accreditation function was assigned to the non-governmental sector. From 2014-2015 is planned to replace the certification by the national institutional and specialized (program) for the accreditation of universities and colleges, since from 2015 public funding will be available only for educational accredited institutions with accredited programs. By 2020, $65 \%$ of universities in the country will undertake an independent national institutional accreditation and $30 \%$ of them will get national program accreditation.

Along with all above stated, there are 2 national accrediting agencies, experience of one of them on engaging students in accreditation was studied in the paper. The results of this work revealed the main difficulties that student-experts came across. They are lack of appropriate knowledge, experience of the students and guidance of the agency. Nevertheless, students believe that during the accreditation of universities or educational programs their opinion is taken in account fully. Moreover, participation in accreditation is considered by student-experts as a valuable life and professional experiences.

For completeness of the results the study requires further consideration of this issue in the second accreditation 
agency of Kazakhstan.

\section{References}

Agreement between the Government of the Republic of Belarus, the Republic of Kazakhstan, the Kyrgyz Republic, the Russian Federation and the Government of the Republic of Tajikistan on the mutual recognition and equivalence of diplomas, academic degrees and titles. (1998, November 24). Retrieved from http://www.russia.edu.ru/information/legal/law/inter/agr_1998/

Bologna process. (2001). Prague Communiqué. Prague: Ministerial conference. Ministers responsible for Higher Education in the countries participating in the Bologna. Retrieved October 23, 2013, from http://www.ond. vlaanderen.be/hogeronderwijs/bologna/documents/MDC/PRAGUE_COMMUNIQUE.pdf

Bologna process. (2003). Berlin Communiqué. Berlin: Ministerial conference. Retrieved October 21, 2013, from http://www.ehea.info/Uploads/about/Berlin_Communique1.pdf

Council for Higher Education Accreditation (CHEA). (1998). Recognition of Accrediting Organizations. Policy and procedures. Washington, DC: CHEA. Retrieved May 2, 2013, from http://www.chea.org/recognition/ CHEA_Recognition_Policy_and_Procedures.pdf

Dearlove, R. (2006). Student involvement in external quality assurance: Results of preliminary survey. In Student involvement in the processes of quality assurance agencies (pp. 32-40). Helsinki: European Association for Quality Assurance in Higher Education (ENQA).

Decree of the President of the Republic of Kazakhstan "On State Program of Education Development in the Republic of Kazakhstan for 2005-2010". (2004, October 11). Retrieved June 16, 2013, from http://adilet.zan. $\mathrm{kz} / \mathrm{rus} / \mathrm{docs} / \mathrm{U} 040001459$

Decree of the President of the Republic of Kazakhstan on Approval of the State Program of Education Development of the Republic of Kazakhstan for 2011-2020. (2010, December 7). Retrieved February 12, 2014, from http://adilet.zan.kz/rus/docs/U1000001118

Education, Audiovisual and Culture Executive Agency. (2012). The European Higher Education Area in 2012: Bologna Process Implementation Report. Retrieved July 9, 2013, from http://www.ehea.info/Uploads/(1)/ Bologna\%20Process\%20Implementation\%20Report.pdf

Elassy, N. (2013). A model of student involvement in the quality assurance system at institutional level (Vol. 2, No. 2, pp. 162-198). Quality Assurance in Education.

European Association for Quality Assurance in Higher Education (ENQA). (2005). Standards and Guidelines for Quality Assurance in the European Higher Education Area. Helsinki: ENQA.

European Association for Quality assurance in Higher education (ENQA). (2006). Student involvement in the processes of quality assurance agencies. Helsinki: European Association for Quality Assurance in Higher Education.

European Commission. (1999). The Bologna Declaration. Retrieved December 13, 2013, from http://www.ond.vlaanderen.be/hogeronderwijs/bologna/documents/mdc/bologna_declaration1.pdf

European University Association (EUA). (2010). Examining quality culture: Part 1-quality assurance processes in higher education institutions. Brussels: EUA. Ministers responsible for Higher Education in the countries participating in the Bologna.

Hernes, G., \& Martin, M. (Eds.). (2008). Accreditation and the global higher education market. International Institute for Educational Planning, Paris. Policy Forum \# 20. Retrieved April 14, 2013 from http://www.iiep.unesco.org/fileadmin/user_upload/Info_Services_Publications/pdf/2008/PolForum_20.pdf

Kalanova, S. (2012). The future of accreditation in Kazakhstan. Accreditation in Kazakhstan. Retrieved September 12, 2013, from http://www.akvobr.ru/nezavisimaja_akkreditacia_v_kazahstane.html

Kalanova, S., \& Omirbaev, S. (2009). National System and educational standards of higher education in the Republic of Kazakhstan. Moscow: Analytical Report.

National Assessment and Accreditation Council (NAAC). (2007). Student Feedback and Participation. Case Presentations. Bangalore. Retrieved October 23, 2013, from http://www.naac.gov.in/Student\%20Feed back\%20and\%20Participation.pdf

National Center of Educational statistics and assessment. (2010). A national report on the state of education development. Astana. Retrieved October 23, 2013, from http://bilimstat.edu.kz/images/nd-2010.pdf 
National Center of Educational statistics and assessment. (2011). A national report on the state of education development. Astana. Retrieved October 23, 2013, from http://bilimstat.edu.kz/images/nd-2011.pdf

National Center of Educational statistics and assessment. (2012). A national report on the state of education development. Astana. Retrieved November 21, 2013 from http://bilimstat.edu.kz/images/nd-2012.pdf

North Central Association of Colleges and Schools. (2013). Higher Learning Commission Decision-Making Bodies and Processes. Retrieved March 23, 2014, from http://www.ncahlc.org/Decision-Making-Bodies /decision-making-bodies.html

Organization for Economic Co-operation and Development (OECD). (2005). Guidelines for quality provision in cross-border higher education. OECD/UNESCO. Paris: Organization for Economic Co-operation and Development.

Palomares, F. M. G. (2012). Consequences of the Student Participation in Quality Assurance, Why should there be students involved in QA? In European Higher Education at the Crossroads. Between the Bologna Process and the National Reforms (Part 1, pp. 361-373). New York: Springer.

Research Center for the Problems of Quality in Specialists` training. (2009). National system and education standards of higher education in the Republic of Kazakhstan: Analytical report (2nd ed.). Re-cast and supplemented. Moscow.

The European Students`Union. (2012). Bologna with student eyes 2012. Brussels: ESU. Retrieved September 11, 2013, from http://www.aic.lv/bolona/2010_12/Reports_2012/BWSE2012-online.pdf

The European Students' Union. (2003). Bologna with student eyes 2003. Retrieved August 12, 2014, from http://esu.ukmsl.net/resources/6068/Bologna-With-Student-Eyes-2003/

The Law on Education. (1999). Retrieved February 10, 2014, from http://adilet.zan.kz/rus/docs/Z990000389_\#z0

The New England Association of Schools and Colleges. (2013). Policy on selection, ethics and responsibilities of Commissioners. Retrieved March 15, 2014, from http://cihe.neasc.org/downloads/POLICIES/Pp10 Selection_Ethics_Responsiblities_Of_Commissioners.pdf

The Republic of Kazakhstan Government regulation on State accreditation rules. (2001). Retrieved January 6, 2014, from http://adilet.zan.kz/rus/docs/P010000976

The resolution of the Government of the Republic of Kazakhstan "On approval of the state accreditation of educational organizations". (2001, July 19).

The Southern Association of Colleges and Schools Commission on College. (2013). Member of Board of Trustees. Retrieved January 12, 2014, from http://www.sacscoc.org/commorg1.asp

The Western Association of Schools and Colleges. (2013a). Peer Review Committees. Retrieved January 12, 2014, from http://www.wascsenior.org/about/committees

The Western Association of Schools and Colleges. (2013b). Commissioners. Retrieved January 12, 2014, from http://www.wascsenior.org/commission/commissioners

United Nations Educational Scientific and Cultural Organization (UNESCO). (2005). Guidelines for Quality Provision in Cross-border Higher Education. Paris: UNESCO.

Wiberg, L. K. (2006). The role of students in the external review of QA agencies: A comparative reflection with the external review of higher education institution. In Student involvement in the processes of quality assurance agencies (pp. 8-11). Helsinki: European Association for Quality Assurance in Higher Education (ENQA).

\section{Copyrights}

Copyright for this article is retained by the author(s), with first publication rights granted to the journal.

This is an open-access article distributed under the terms and conditions of the Creative Commons Attribution license (http://creativecommons.org/licenses/by/3.0/). 